\title{
ADDRESS OF WELCOME TO THE PARTICIPANTS IN THE
}

\section{THIRD INTERNATIONAL SYMPOSIUM ON ANTARCTIC}

\section{GLACIOLOGY}

\author{
by \\ Dr Edward $\mathrm{H}$. Jennings \\ President, The Ohio State University
}

I am delighted to have this opportunity to welcome you to The Thio State University. And I am especially pleased that ohio State is able to join with the National Academy of Sciences to serve as co-hosts for this important meeting, the third International Symposium on Antarctic Glaciology. The symposium is being generously supported by the Scientific Committee on Antarctic Research and the National Science Foundation as well as by our University. Thio State and NSF have been working together for many years in the area of polar studies. And the relationship has been extremely productive and mutually rewarding.

This University is certainly a logical place to hold a meeting of this kind. Although I am a newcomer at this institution, I soon became aware of ohio State's Institute of Polar Studies and the important work that has been going on here for many years. And I an extremely impressed. I might also add that a large, comprehensive university, such as Ohio State, provides an ideal "home base" for a research program, such as the Institute of Polar Studies. Here, on one campus, you will find scientists from many disciplines. You will find outstanding library and laboratory facilities. You will find outstanding faculty and students in many fields. They come from all parts of the world. But, most important, you will find a climate that fosters research.

A 11 of these things combine to provide an unusually solid foundation on which a program, such as the Institute of Polar Studies, can be established and flourish, and a solid foundation on which to build the productive partnership that ohio state has enjoyed with the National Science Foundation for so many years.

One of my first duties as president was to preside last week at the University's Commencement ceremonies. During the ceremony we presented the 'Iniversity's Distinguished Service Award to a number of emeritus faculty members who are outstanding leaders in their fields. Among that group was Or Richard Goldthwait, who was the founder and first Director of the Institute of Polar Studies at Ohio State. His successor as Director was Dr Colin Bull, who is now Dean of the College of Mathematical and Physical Sciences and, as Chairman of the Steering Cominittee for your symposium, was responsible for bringing it, and you, to Columbus. He was followed as Director by Dr Emanuel Rudolph, now Chairman of our Department of Botany. And the current Director of the Institute and the person who is now serving as the Chairman of the Local Committee for this symposium is Dr David Elliot.

These four gentlemen, each a distinguished scientist in his own right, span the twenty-one years that the Institute has been in existence. They have developed and continued what has become one of the major polar and glaciological research programs in the world. We are very proud of what they and their colleagues have achieved, both in terms of their contributions to science and in terms of the international ties that have been established with you and other scientists throughout the world.

I am told that there are fourteen countries represented here today. To me, your symposium underscores once again the immense possibilities for progress that exist when people and nations work together in the pursuit of common goals. The scientific community is not immune to political and economic changes, however. We all know this is true. Yet this meeting, and others like it, provide for the rest of the world a vitally important example of the goal we all seek: the goal of international understanding and cooperation, a goal that seems to remain just out of reach in so many other sectors of human endeavor.

And so it is my belief that beyond the important topics you will be discussing related to Antarctic glaciology, and beyond their importance to the world community of science, your meeting carries with it a special significance for all persons. It serves as a needed reminder of the immense possibilities for progress that exist when dedicated individuals from all parts of the world, such as you, come together to work on mutual interests and problems in an atmosphere of cooperation.

Let me conclude with this thought. There is an underlying urgency about your meeting. You know this better than I. But it has become increasingly clear that, as man intrudes himself into every corner of the globe, we run great risks. We need to understand our fragile world much better than we do before we capriciously unleash upon it the full force of man's technology. Clearly, we do not know enough about such things as the greenhouse effect, for example. But evidence is mounting that points to the huge changes in our climate, and especially in the Antarctic which will take place if we continue to burn fossil fuels at the present rate. We look to you of the scientific community for the data and the understanding of such problems that will help our countries chart a safe course through the hazards that lie ahead. We need the kind of guidance that onty you can provide.

Again, I want to welcoine you to the University and to tell you how pleased we are to have you here. I know that your meetings will be stimulating and productive. And I wish you great success in your important deliberations. Thank you. 
https://doi.org/10.3189/S026030550000241X Published online by Cambridge University Press 